\title{
Executive Compensation and Corporate Debt Policy and Monitoring
}

\author{
Dongxu Yang ${ }^{1, *} \operatorname{Tian}^{\text {Tan }}{ }^{2}$ Shizhong Xiong ${ }^{1}$
}

\begin{abstract}
${ }^{1}$ Department of Accounting, Xinhua College of Sun Yat-Sen University, Guangzhou, Guangdong, China
${ }^{2}$ Huashang College Guangdong University of Finance \& Economics, Guangzhou, Guangdong, China

*Corresponding author. Email: yang.dongxu@hotmail.com
\end{abstract}

\begin{abstract}
Both debtor monitoring and corporate risk-taking are very interested to researchers, but how does these two come together and interplay in terms of executive compensation contract structuring? This paper intends to shed light on this question in the following dimensions. First, we have documented that firms with high leverage (Risk) grant executives with low Vega sensitivity, because bondholder have disincentive to taking risk beyond necessary, and the respective firms are likely to put constrains on executive risk-taking behavior through compensation contract. Furthermore, the results show that such effective monitoring could be accomplished by greater usage of short-term lending and hence requiring firm to roll-over the debt period by period. Lastly, this result is robust weakly to all top five executives, and robust strongly throughout the accounting standard transition period.
\end{abstract}

Keywords: executive compensation, leverage, risk taking behavior

\section{INTRODUCTION}

The executive compensation literature has studied the contracting incentives and executives' decision making in terms of risk behavior. Coincidentally, the debtor has long aware of the contracting problem which may diminish their value in the company. To address this issue, this paper documented that firms with high leverage grant executives with low Vega sensitivity, because bondholder have disincentive to taking risk beyond necessary, and the compensation package design serves as an effective tool for bondholder to control the executives' risk orientation.

On the practical side, we have personally consulted with a senior director, who has worked for a large European bank for about 30 years, and whose daily job is responsible for project lending and supervision. Although she has mentioned that her bank is unlikely put people on the large client's board or take measurement of direct controlling the client's CEO compensation incentives, the bank has formed a special supervision committee to monitor the client in case of fraud commitment. She also admitted that she has prior acknowledgment of the bondholder and shareholder incentive conflict, believing that too much risk bearing is inappropriate to her bank's own interest.

In some other case, when Gome Electrical Appliances asked for a large sum of borrowing from Bain Capital, the lender indeed insists on putting two seats on the client's board. As these board seats possess high voting power, risk-seeking CEOs are unlikely to win the campaign for the future elections. In conclusion, the leverage ratio has strong influence on the companies' risk appetite through political negotiation and campaign.

\section{LITERATURE REVIEW}

Prior literature has documented a positive (negative) relationship between Vega (Delta) from executive option holding and firm's risk-taking behavior (Knopf, Nam, and Thornton, 2002; Coles, Daniel, and Naveen 2006). The previous rationality is general true for $R \& D$ (Coles et al. 2006) and Investment decision, but when it comes to financial leverage, companies are facing different type of risk - financial constrain, and corporate decisions are governed by a different composition of stakeholders. Classical finance literature has document that shareholders try to exploit bondholder welfare by investing in higher risk-class assets; this phenomena commonly refers to "asset substitution" (Fama and Miller, 1972; Jensen and Meckling, 1976). As bondholders play a major role in the highly leveraged firms, it is optimal for such company to structure its CEO compensation with lower Vega, because high risk rewards shareholder more, but almost provide no benefit for bondholder. In addition, under the Black-Scholes option pricing model, high leverage firms will have much greater firms' debt value sensitivity to their volatility (Anderson and Core, 2011 working paper), and that means bondholder will expose to tremendous risks in these type of firms. In such firm, bondholder would demand the compensation board to 
offer low Vega sensitivity for the executive pay package. It is not uncommon for bondholder to increase monitoring in unfavorable scenario, as debt contracting increases firm's conservatism. For example, Gilson (1990) finds that creditors will increase their direct monitoring by restricting and tightening covenants on financial and investment policy in private lending agreements, during Chapter 11 bankruptcy filing or debt restructuring event. Anderson and Core (2011 working paper) has also documented the negative correlation between Vega and leverage, though Coles et al. (2006) documented a positive one. From above reasoning, the result expects a negative relationship between Vega and firm's leverage.

As previously mentioned, high leverage is negatively associated with Vega incentive. Taking the perspective from the other side, what causes the association between low leverage and high Vega? The simplest observation from Figure 1 in Core and Guay (2002) concludes that Vega is negatively correlated with profitability - price to strike ratio. The ratio of year-end stock price to strike price can effectively serve as a proxy for profitability, because the strike prices came from the current year new grants and prior years' old grant. The higher the prices to strike ratios are, the more profitable is the company for the past granting periods. In addition, theoretical finance predicts a positive correlation between firms' leverage and profitability. Only the profitable firm has capacity to take on additional debt and use the related interest expense to shield its profit. Hence, the net effect is that Vega is negatively correlated with leverage ratio and profitability. From the perspective of low leverage to high Vega, when firm is not running so efficiently, evidenced by low profitability and low leverage ratio, the compensation board needs to grant its CEO with high Vega portfolio to encourage the CEO to take on additional risky projects, in hoping that such inducement can rejuvenate the company.

In empirical finance literature, both profitability and firm size are weakly negatively correlated with leverage, which means that profitable companies (or large firms) are not levered enough to take advantage of the tax shield, primarily reflecting the risk aversion of the manager. As Delta is positively correlated with profitability, it is reasonable to expect a weak negative correlation between Delta and leverage. Executives, with high Delta incentive, are risk-averse and therefore unlikely take on too much debt.

\section{HYPOTHESIS}

H3a: High leverage firm granted CEO and top management team compensation structure with lower Vega, since Vega has incentive conflict with bondholder.
H3b: CEO and top management team with Higher Delta adopt lower leverage policy, since high Delta induces risk aversion for undiversified executive.

Brockman, Martin, and Unlu (2010) documented a negative (positive) relation between CEO portfolio Deltas (Vegas) and short-maturity debt proportion (debt matured in five years divided by total debt). Their Delta is negatively correlated with short-maturity debt proportion, and hence positively correlates with longmaturity debt proportion (debt matured longer than 5 years). Their risk story will break down for the positive correlation: why do risk-averse manager will borrow that much long-maturity debt? Instead, our results reported that Delta is positively correlated with current debt proportion (percentage of current debt to total debt), since short-term debt is not embedded with any long-run risk premium and hence less risky. For longterm bond, long-run risk premium is often charged into the interest rate as bondholder perceives that additional risk is created due to the absence of frequent control and monitoring of the client business. If the managers genuine perceive the risk of debt in the same fashion as bondholder does, and if they believe the monitoring of the banker as another piece of valuable inputs to the uncertainty environment, the risk-averse manager with high Delta would prefer the short-term Debt. From the above reasoning, the paper predicts a positive relationship between Delta and proportion of short term Debt proportion.

On the other hand, Vega firm is positively associated with short-maturity debt proportion (Brockman, Martin, and Unlu, 2010); and hence Vega is negatively correlated with long-maturity debt proportion. Again, the negative correlation is not reasonable: why does risk-seeking CEO dislike longmaturity debt, where lies plenty of uncertainty? However, this paper has documented that Vega is positively correlated with current debt proportion, since high Vega has incentive conflict with bondholders, especially for the long-term one as demonstrated in hypothesis 3a. Even in high Vega firms, where the monitoring is needed most, through short-term lending, the creditors can effectively control the managers action by requiring them to roll-over the debt period by period. In sum, Vega should be positively correlated with short-term debt proportion.

$\mathrm{H} 3 \mathrm{c}$ : Vega is positively correlated with short-term debt proportion, since bondholder requires greater monitoring for the high Vega (risk seeking) firms.

H3d: Delta positively correlated with short-term debt proportion, primarily in reflecting those managers' anxiety to long-run uncertainty and risk. 


\section{RESUlt ANALYSIS}

"Table I" shows the pay for performance sensitivity on book leverage: From Model 1 to 5, Vega presents significant negative coefficients, and Delta also shows significant negative coefficients. They perfectly match with our expectation in that high leverage firms, dominated by bondholders, will constrain executive's risk-taking behavior through compensation incentive monitoring, such as decreasing Vega. In case of Delta, option high in the money (evidenced by high Delta) will also discourage firm from risk-taking, such as entering into new debt contracts, because executives perceive the additional risks as unnecessary and threatening to their in-the-pocket money from options. Although Coles et al. (2006) presents contrary result, our finding is consistent with many classical finance theories, including bondholder and shareholder incentive conflict (Fama and Miller, 1972; Jensen and Meckling, 1976), and also consistent with Anderson \& Core's working paper (see "Table IV" and "Table VI" from Anderson and Core's 2011 working paper). Anderson \& Core's paper also shows that Vega monotonically decreases with leverage and presents similar result to this paper.

In "Table I", Model 1 and 2 started the regression model with the basic specification as the one in Coles et al. (2006). Model 3 added three control variables: "prof_a", profitability (OIBDP /Total Assets); and "tang_a", tangibility (PP\&E /Total Assets); "Z score", a proxy for bankruptcy. Thereafter, the $\mathrm{R}$ square has surged from $15 \%$ to $24 \%$. Insufficient control of correlated variable (to variable of interest) gives rise to the omitted variable bias problem, and the main interpretation could be wrong. Model 4 inputs the topmanagement-team's Delta and Vega, and the results still hold for CEO, but not all hold for top-managementteam due to high correlation between the two groups of incentive variables. Admittedly, the CEO's compensation often highly correlated with other top management team members in the same company, and that is one of imperfection we have to accept. Model 5 selected companies with at least 4 reported top executives in compensation database. As this group of companies is bigger in size and greater for sales figure, the coefficients on the interested variables show much greater economic significance. Model 6 lists all the top management team members' Delta and Vega, regardless of their position as CEO or not. The results still hold to some extent, and unfortunately, Model 6 is contaminated by the high correlation among executives' Delta and Vega.

TABLE I. REGRESSION ANALYSIS: BOOK LEVERAGE AND INCENTIVES BETWEEN 1992 AND 2002

\begin{tabular}{|c|c|c|c|c|c|c|c|c|c|c|c|c|c|}
\hline & Model1 & & Model2 & & Model3 & & Model4 & & Model5 & & & Model6 & \\
\hline & Industry FE & & Firm FE & & Firm FE & & Firm FE & & Firm FE & & & Firm FE & \\
\hline totalvega & -0.0355 & $*$ & -0.0365 & $*$ & -0.041 & $* *$ & -0.0308 & & -0.0805 & $* *$ & totalvega_1 & -0.0333 & \\
\hline totaldelta & -0.0078 & $* * *$ & -0.0077 & $* * *$ & -0.0059 & $* * *$ & -0.0062 & $* * *$ & -0.0071 & $* * *$ & totaldelta_1 & -0.0088 & $* * *$ \\
\hline Tenure & 0.0009 & $* * *$ & 0.0009 & $* * *$ & 0.001 & $* * *$ & 0.001 & $* * *$ & 0.0011 & $* * *$ & Cashcomp_1 & 0.0052 & \\
\hline Cashcomp. & -0.003 & $* * *$ & -0.003 & $* * *$ & -0.0061 & $* * *$ & 0 & & 0.0009 & & totalvega_2 & -0.0282 & \\
\hline totalvega_topmgnt & & & & & & & -0.0059 & & 0.0049 & & totaldelta_2 & 0.0167 & \\
\hline totaldelta_topmgnt & & & & & & & 0.0063 & $* *$ & 0.0079 & $* *$ & Cashcomp_2 & 0.0015 & \\
\hline Cashcompensation_t & & & & & & & -0.0045 & $* * *$ & -0.0044 & $* * *$ & totalvega_3 & -0.1255 & \\
\hline logsale & 0.0394 & $* * *$ & 0.0394 & $* * *$ & 0.0385 & $* * *$ & 0.0389 & $* * *$ & 0.038 & $* * *$ & totaldelta_3 & 0.0355 & \\
\hline $\mathrm{mk} 2 \mathrm{bk}$ & -0.0126 & $* * *$ & -0.0126 & $* * *$ & -0.0093 & $* * *$ & -0.0106 & $* * *$ & -0.0105 & $* * *$ & Cashcomp_3 & -0.0249 & $* * *$ \\
\hline Surpluscash & 0.049 & $* * *$ & 0.0491 & $* * *$ & 0.0774 & $* * *$ & 0.0743 & $* * *$ & 0.0231 & & totaldelta_4 & -0.0006 & \\
\hline Sales growth & -0.0019 & & -0.0016 & & -0.0006 & & -0.0014 & & 0.0004 & & Cashcomp_4 & 0.0131 & \\
\hline Stockreturn & -0.0182 & $* * *$ & -0.0186 & $* * *$ & -0.0126 & *** & -0.0129 & $* * *$ & -0.0147 & **** & logsale & -0.0007 & \\
\hline zscore & & & & & -0.0226 & $* * *$ & -0.0226 & $* * *$ & -0.0182 & $* * *$ & $\mathrm{mk} 2 \mathrm{bk}$ & 0.0405 & $* * *$ \\
\hline prof_a & & & & & -0.1317 & *** & -0.1393 & $* * *$ & -0.1556 & **** & bl & -0.0136 & $* * *$ \\
\hline \multirow[t]{6}{*}{ tang_a } & & & & & 0.2129 & $* * *$ & 0.2138 & $* * *$ & 0.2209 & $* * *$ & Surpluscash & 0.0343 & \\
\hline & & & & & & & & & & & Salesgrowth & -0.0014 & \\
\hline & & & & & & & & & & & Stockreturn & -0.0155 & $* * *$ \\
\hline & & & & & & & & & & & zscore & -0.0321 & $* * *$ \\
\hline & & & & & & & & & & & prof_a & 0.0015 & \\
\hline & & & & & & & & & & & tang_a & 0.1984 & $* * *$ \\
\hline $\mathrm{N}$ & 8682 & & 8702 & & 8702 & & 8702 & & 5560 & & & 5328 & \\
\hline $\mathrm{R}^{\wedge} 2$ & 0.15 & & 0.15 & & 0.24 & & 0.24 & & 0.21 & & & 0.23 & \\
\hline Firmfix & & & Yes & & Yes & & Yes & & Yes & & & Yes & \\
\hline h $2 \mathrm{di}$ & Yes & & & & & & & & & & & & \\
\hline
\end{tabular}

In "Table II" Model 3 and 4, Vega carries a positive significant coefficient for short-term debt proportion, demonstrating that for high Vega firms, who need greater extend of monitoring, bondholder prone to use short-term debt instrument. The result is stronger in model 7 after controlling for firm's preference of using debt financing ("BL2", short-term debt level as a proxy). In Pearson correlation study, Vega is also positively correlated with short-term debt proportion 
and negatively correlated with long-term debt proportion.

The results, in "Table II" Model 5 and 7 with OLS specification, have documented positive coefficients for Delta on proportion of short-term debt. High Delta firms use greater proportion of short-term debt, primarily reflecting the risk aversion of top executives when their options are high in the money. Pearson correlation also shows that Delta is positively correlated with short-term debt proportion and negatively correlated with long-term debt proportion. Although Model 1 to 4 show that Short-term debt level is negatively correlated with Delta, which is consistent with Brockman et al. (2010), we remain silent on such interpretation, because fix effect regression specification is not intended for cross-sectional interpretation among firms.

TABLE II. REGRESSION ANALYSIS: FIRMS' DEBT POLICIES AND INCENTIVES BETWEEN 1992 AND 2002

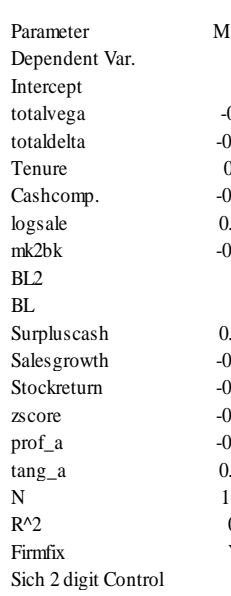

$\begin{array}{cccccc}\begin{array}{c}\text { Model1 } \\ \text { BL }\end{array} & & \begin{array}{c}\text { Model2 } \\ \text { BL2 }\end{array} & \begin{array}{c}\text { Model3 } \\ \text { BL3 }\end{array} \\ & & & & & \\ -0.048 & * * * & -0.1461 & * * * & 0.0467 & * * \\ -0.0077 & * * * & -0.0034 & * * * & -0.0028 & * \\ 0.001 & * * * & 0.0002 & & 0.0001 & \\ -0.0062 & * * * & 0.0124 & * * * & 0.0083 & * * \\ 0.0386 & * * * & 0.0086 & * * * & 0.0223 & * * \\ -0.0086 & * * * & 0.0008 & & 0.0118 & * * * \\ & & & & & \\ & & & & & \\ 0.0831 & * * * & 0.0886 & * * * & -0.0562 & * * * \\ -0.0011 & & 0.0036 & * * & -0.0047 & \\ -0.0062 & * * & -0.0059 & * * * & -0.0203 & * * \\ -0.0119 & * * * & -0.0331 & * * * & -0.0018 & * * \\ -0.2275 & * * * & 0.2614 & * * * & 0.1181 & * * \\ 0.2226 & * * * & -0.0721 & * * * & -0.1752 & * * * \\ 11499 & & 11735 & & 11735 & \\ 0.22 & & 0.44 & & 0.03 & \\ \text { Yes } & & \text { Yes } & & \text { Yes } & \\ & & & & & \end{array}$

$\begin{array}{cc}\text { Model4 } & \text { BL3 } \\ & \\ 0.1036 & * \\ -0.0015 & \\ 0 & \\ 0.0035 & * \\ 0.0189 & * \\ 0.0115 & * \\ 0.3898 & * \\ & \\ -0.0907 & * \\ -0.0061 & * \\ -0.018 & * \\ 0.0111 & * \\ 0.0162 & \\ -0.1471 & * \\ 11735 & \\ 0.07 & \\ \text { Yes } & \end{array}$

$\begin{array}{ccc} & \text { Model } & \\ \text { BL3 } & \\ & 0.16486 & * * \\ * * * & 0.12036 & * * \\ & 0.00408 & * \\ & -0.00146 & * * \\ * * * & 0.01229 & * * \\ * * * & 0.00788 & * * * \\ * * * & 0.0188 & * * \\ * * * & & \\ & & \\ * * * & -0.11648 & * * \\ * * & -0.00178 & \\ * * * & -0.01847 & * * \\ * * * & -0.0027 & * \\ & 0.1236 & * * \\ * * * & -0.25909 & * * \\ & 10305 & \\ & 0.09 & \\ & \text { OLS } & \end{array}$

$\begin{array}{ccc} & \text { Model6 } & \\ & \text { BL4 } & \\ * * & 0.83514 & * * \\ * * & -0.12036 & * * \\ * & -0.00408 & * \\ * * & 0.00146 & * * \\ * * & -0.01229 & * * \\ * * & -0.00788 & * * \\ * * & -0.0188 & * * \\ & & \\ & & \\ * * & 0.11648 & * * \\ & 0.00178 & \\ * * & 0.01847 & * * \\ * * & 0.0027 & * * \\ * * & -0.1236 & * * \\ * * & 0.25909 & * * \\ & 10305 & \\ & 0.09 & \\ & \text { OLS } & \end{array}$

$\begin{array}{cccc}\text { Model7 } & & \text { Model } & \\ \text { BL3 } & & \text { BL4 } & \\ 0.27213 & * * * & 0.72787 & * * * \\ 0.06224 & * * & -0.06224 & * * \\ 0.00106 & & -0.00106 & \\ -0.00161 & * * * & 0.00161 & * * * \\ 0.00768 & * * * & -0.00768 & * * * \\ 0.01343 & * * * & -0.01343 & * * * \\ 0.01279 & * * * & -0.01279 & * * * \\ & & & \\ -0.36 & * * * & 0.36 & * * * \\ -0.09311 & * * * & 0.09311 & * * * \\ -0.000672 & & 0.000672 & \\ -0.02084 & * * * & 0.02084 & * * * \\ -0.00705 & * * * & 0.00705 & * * * \\ 0.04404 & & -0.04404 & \\ -0.21526 & * * * & 0.21526 & * * * \\ 10305 & & 10305 & \\ 0.16 & & 0.16 & \\ \text { OLS } & & \text { OLS } & \\ & & & \end{array}$

${ }^{\text {a. }}$ Dependent variables for following models: Book Leverage (BL) / Short-term debt over asset (BL2) / Short-term debt ratio (BL3) / Long-term debt ratio (BL4)

\section{ROBUSTNESS CHECK}

There two different methods to construct option Delta and Vega: using "full information" calculation after 2006 and "OA proxy method" stated in Core and Guay (2002). Post-2006 results are performed separately and extensively for robustness checks. The results for sample period between 2006 -2011 and between $1992-2006$ are qualitative the same as the above results. For page limit, they are omitted here, and they are available upon request.

\section{DATA AND METHODOLOGY}

Execucomp database incorporates data from executive compensation, including salary, bonus, and option for the top five executives in descending order for the total pay package. The paper investigated the entire population firms from the "S\&P 500, S\&P Midcap 400, and S\&P Smallcap 600". For the old Execucomp format, the sample period starts from 1992 to 2006, during which the "OA proxy method" is needed for Delta and Vega calculation. The new format data starts from 2006 and corresponds to a more comprehensive set of disclosure under FAS123R.

The following treatments are adopted to refine sample: delete firm observations with negative total assets; exclude financial and utility firms; and use the total number of options, including new grant during the year, prior vested and unvested stock options to capture executives' total incentives. In fact, Core and Guay (2002a) has pointed out that the Deltas of newly granted options have very little correlation with the ones granted from previously periods. "Table III" Panel A shows the descriptive statistic in sample period between 1992 and 2002. CEO has an average Vega and Delta for 100 and 570 in executive wealth sensitivity. Top management team other than CEO has an average Vega and Delta for 125 and 537 in executive wealth sensitivity. Coles et al. (2006) has a comparable descriptive statistics for the same sample period: CEO have an average Vega and Delta for 80 and 600 in executive wealth sensitivity; Top management team other than CEO have an average Vega and Delta for 122 and 787 in executive wealth sensitivity; But there is an unexpected large standard deviation for Coles's Topmanagement-team Delta. "Table III" Panel B presents the statistics for all other financial variables for sample. In sum, the following descriptive statistics are qualitative similar to the ones in Coles et al. (2006). Additional check on variable correlation presents little problem for multicollinearity. 
TABLE III. DESCRIPTIVE STATISTICS FOR DEPENDENT AND INDEPENDENT VARIABLES BETWEEN 1992 AND 2002

\begin{tabular}{|c|c|c|c|}
\hline \multicolumn{4}{|l|}{ Panel A } \\
\hline \multicolumn{4}{|l|}{ CEO } \\
\hline Variable & $\mathrm{N}$ & Mean & Std Dev \\
\hline totalvega & 9,589 & 100 & 142 \\
\hline totaldelta & 9,608 & 568 & 1,100 \\
\hline Cashcompensation & 9,608 & 1,347 & 971 \\
\hline Tenure & 9,804 & 6 & 7 \\
\hline PAGE & 9,768 & 66 & 8 \\
\hline \multicolumn{4}{|l|}{ Top-management team } \\
\hline totalvega_topmgnt & 13,374 & 125 & 375 \\
\hline totaldelta_topmgnt & 13,414 & 537 & 2,421 \\
\hline Cashcompensation_t & 13,414 & 2,270 & 2,670 \\
\hline \multicolumn{4}{|l|}{ Panel B } \\
\hline Variable & $\mathrm{N}$ & Mean & Std Dev \\
\hline CAPX & 9476 & 0.07 & 0.06 \\
\hline$R \& D$ & 9476 & 0.04 & 0.08 \\
\hline Investment & 9476 & 0.05 & 0.10 \\
\hline Market-to-Book & 9451 & 2.02 & 2.83 \\
\hline Zscore & 9476 & 1.81 & 2.29 \\
\hline Profitability & 9476 & 0.14 & 0.14 \\
\hline Tangibility & 9476 & 0.32 & 0.22 \\
\hline Book leverage & 9277 & 0.32 & 0.23 \\
\hline Markert Leverage & 9451 & 0.21 & 0.20 \\
\hline DebtIssue & 9476 & 0.02 & 0.09 \\
\hline EquityIssue & 9476 & 0.00 & 0.09 \\
\hline CEO-AGE & 9444 & 66.01 & 8.18 \\
\hline Tenure & 9476 & 6.51 & 6.87 \\
\hline SALE & 9476 & 4,377 & 12,537 \\
\hline
\end{tabular}

\section{A. Dependent variables}

Book Leverage (BL) uses total book debt divided by book value of assets. Short-term Debt proportion is calculated as percentage of short-term debt to total debt.

\section{B. Independent variables of interest}

Delta measures the sensitivity of CEO wealth (stock and options components) to stock price movement. Delta perfectly aligns the incentives of managers to the interests of shareholders, since first derivative of executive option value respect to price (Delta) is always positive. J.L. Coles et al. (2006) argue that Delta can also entail managers more risk. As managers are relatively undiversified comparing to their diversified shareholders and therefore greater exposure to firms' idiosyncratic risks, they will display more traits of riskaversion. For example, managers may disregard some positive net present value (NPV) projects if they are out of managers' risk tolerance.

Vega provides the convex payoff structure of an option, and such payoff scheme can potentially offset the aversion to risk of a typical manager. J.L. Coles et al. (2006) also demonstrate that CEOs, who have compensation package with higher Vega sensitivity, conduct corporate policy at higher risk level, namely greater investment in R\&D, higher leverage, and less investment in PPE.

\section{Control variables}

The regression models have incorporated a wide list of commonly used financial control variables, including Market-to-Book, Surplus Cash, Sales Growth, Stock Return, Tangibility, Z score, and Profitability (OIBDP /Book value of assets).

\section{CONCLUSION}

This paper made several important contributions to contracting incentives study. First of all, we have documented that firms with high leverage grant executives with low Vega sensitivity, because bondholder have disincentive to take risk beyond necessary, and the respective firms are likely to put constrains on executive risk-taking behavior through compensation contract setting. Furthermore, the results conclude that such effective monitoring could be accomplished by greater usage of short-term lending and hence requiring firm to roll-over the debt period by period. This finding is consistent with the governance role of debt instrument. Lastly, the results for post-2006 period are qualitatively the same as pre-2006 period. 


\section{References}

[1] Anderson, J. and Core, J., 2011. Measuring managerial incentives to increase firm volatility provided by debt, stock, and options. (Working Paper)

[2] Brockman, P., Martin, X. M., and Unlu, E., 2010. Executive Compensation and the Maturity Structure of Corporate Debt. Journal of Finance 65(3), 1123-1161.

[3] Coles, J., Daniel, N., and Naveen, L., 2006. Managerial incentives and risk-taking. Journal of Financial Economics 79, 431-468.

[4] Core, J. and Guay, W., 2002a. Estimating the value of employee stock option portfolios and their sensitivities to price and volatility. Journal of Accounting Research 40, 613-630.

[5] Fama, E. F. and Miller, M. H., 1972, The Theory of Finance (Holt, Rinehart, and Winston, New York).

[6] Gilson, S. C., 1990. Bankruptcy, Boards, Banks, and Blockholders. Journal of Financial Economics (27), 355-387.

[7] Jensen, M. C., and William H. M., 1976, Theory of the firm: Managerial behavior, agency costs, and ownership structure. Journal of Financial Economics 3, 305-360.

[8] Knopf, J. D., Nam, J., and Thornton J. H., 2002, The volatility and price sensitivities of managerial stock option portfolios and corporate hedging. Journal of Finance 57, 801-812. 